\title{
Effect of psycho educational intervention on level of anxiety among Hospitalized children: A systemic Literature review
}

\author{
Ms. Niyati Patel 1, Mr. Vipin Vageriya ${ }^{2 *}$ \\ ${ }^{1}$ M.Sc. Nursing Student, MTIN-CHARUSAT-Changa, Ta.-Petlad Dist. Anand(Gujrat)-388421, India \\ ${ }^{2}$ Asst. Professor, Pediatric Department, MTIN-CHARUSAT-Changa, Ta.-Petlad Dist. Anand(Gujrat)-388421, India
}

\begin{abstract}
Background: Hospitalization and Disease can be the first crisis situation that a child encounters. Hospitalization may leads to increase the stress and level of anxiety among children and parents. An excessive or persistent state of anxiety can have a devastating effect on child's physical and mental health. Psych education is an evidence-based therapeutic intervention for clients and their family members who help them to cope with illness and give the information as well as support to understand in better way. Psych education is helps to children and their family to minimize the emotional trauma during the hospital stay.

Objective: To evaluate the impact of psycho educational intervention on level of anxiety among hospitalized children.

Methods: A systematic literature review is conducted.

Electronic database search to Collect Literature: The following electronic databases are searched: ProQuest, Research gate, Pub med, EBSCO, science direct, the British Nursing Index and the Cumulative Index to Nursing \& Allied Health Literature (CINHAL) and journal available in library.

Result: collected review of literature result shows that psycho educational intervention considers a positive effect on reduce the level of anxiety among hospitalized children.

Conclusion: psych educational intervention is cluster of the strategies like play therapy, storytelling, guided imagery etc. It is a non- invasive and safe intervention which helps to reduce the anxiety level.

Keywords: psych educational intervention, anxiety level, hospitalized children, search engine, counselling
\end{abstract}

Article Info: Received 18 June 2019; $\quad$ Review Completed 14 August 2019; $\quad$ Accepted 17 August 2019; Available online 30 August 2019

Cite this article as:

Patel N, Vageriya V, Effect of psycho educational intervention on level of anxiety among Hospitalized children: A systemic Literature review, Journal of Drug Delivery and Therapeutics. 2019; 9(4-s):855-860

http://dx.doi.org/10.22270/jddt.v9i4-s.3389

*Address for Correspondence:

Mr. Vipin Vageriya, Asst. Professor, Manikaka Topawala Institute of Nursing, CHARUSAT-Changa, Ta.-Petlad Dist. Anand(Gujrat)-388421, India

\section{What is known to study?-}

This study is belongs to literature review which shows that many of the researcher worked on anxiety. The types of anxiety vary according to age and causes of anxiety. Researchers used various tools to measure the level of anxiety. This study search specific to anxiety among children regarding hospital stay and invasive procedure during hospital stay.

\section{What new things add in study-?}

This paper helps to identify various tools used by researcher to assess the level of anxiety in hospitalized children. The primary objective is to describe anxiety measurement instruments used in children.

The most commonly used instrument was the State-Trait Anxiety Inventory, The Screen for Child Anxiety Related Disorders (SCARED) Children's Manifest Anxiety Scale-
Mandarin version, PROMIS, Pediatric Anxiety Short Form, State-Trait Anxiety Inventory, Faces Pain Scale-Revised and 10-cm Visual Analogue Scale, both adapted for anxiety) were used.

\section{Back ground of study-}

Hospitalization is a threatening and stressful experience for many children if they are immature. As children's are unfamiliar with the environment and medical procedures and unaware of the reasons for hospitalization, it can result in children's anger, uncertainty, anxiety and feelings of helplessness. Play is an important part of nursing care for children. Play offers, the child, an opportunity or creative expression, diversion and effective coping.

According to several studies, preschool children have more hospital related fears than older children because of their developmental stage (Gazall \& Mactie 2007). The preschool 
children are not always able to separate reality from the imaginary and the child's ability to express and cope with his or her fears is limited. According to parents, $83 \%$ of preschool children suffer from different kinds of anxiety symptoms related to hospital fears (Hus 2004).

Hospitalization and Disease can be the first crisis situation that a child encounters. Hospitalization may leads to increase the stress and level of anxiety among children and parents. An excessive or persistent state of anxiety can have a devastating effect on child's physical and mental health. Psych education is an evidence-based therapeutic intervention for clients and their family members who help them to cope with illness and give the information as well as support to understand in better way. Psych education is helps to children and their family to minimize the emotional trauma during the hospital stay.

Anxiety is common nature of human being. Only human can express the anxiety. Anxiety is considered as sign of depression or psychological problem. Many researches had been carried out research on anxiety and its causes, anxiety and its treatment strategies, school admission and anxiety among children, hospitalization and anxiety etc. It is considered as early sign of depression. Early support can reduce the level of anxiety. The anxiety is commonly present in following conditions like-

- Social anxiety

- Anxiety during Hospital a admission

- $\quad$ Specific phobias

- Panic disorder

- $\quad$ Generalised anxiety disorder (GAD)

- $\quad$ Post-traumatic stress disorder (PTSD)

- Obsessive compulsive disorder (OCD)

Hospitalization is seen as an extremely disturbing situation in the life of a person, since it includes decline of health condition and removal from family and social contexts. This fact gains proportion when it happens to a child, for besides changing the family routine, it may cause changes in the child's development and lasting consequences, including anxiety.

By definition, anxiety consists of an emotional state with psychological, social, and physiological components that may affect individuals at any stage of their development.

The common symptoms of anxiety are-nervousness, restlessness, being tense, feelings of danger, rapid heart rate, rapid breathing, or hyperventilation, increased or heavy sweating, trembling or muscle twitching of muscles, weakness and lethargy, poor concentration, insomnia and physiological symptoms related to GI tract.

\section{METHODS}

Literature searching through internet requires a planned strategy for appropriate finding. It was searched by key words like Anxiety among children, Hospital Anxiety, Play therapy, therapeutic intervention etc. A systematic search for anxiety related psycho educational intervention is conducted. The literature review is designed as a narrative study, because a broader perception of children is different in various conditions. The article include from various country. It will help us to know that what research has been carried out in this field.

\section{Search strategy}

A systematic electronic search is used to identify number of studies carried out on psycho educational intervention on level of anxiety among Hospitalized children in terms of play, diversion, storytelling etc. The original research papers are only included in study. The following electronic databases were searched: , online journal sites, ProQuest, Embase, Pubmed, PsycARTICLES, EBSCO, Scopus, Educational Resources Information Center(ERIC), the British Nursing Index and Cumulative Index to Nursing \& Allied Health Literature (CINHAL) and journal available in library.

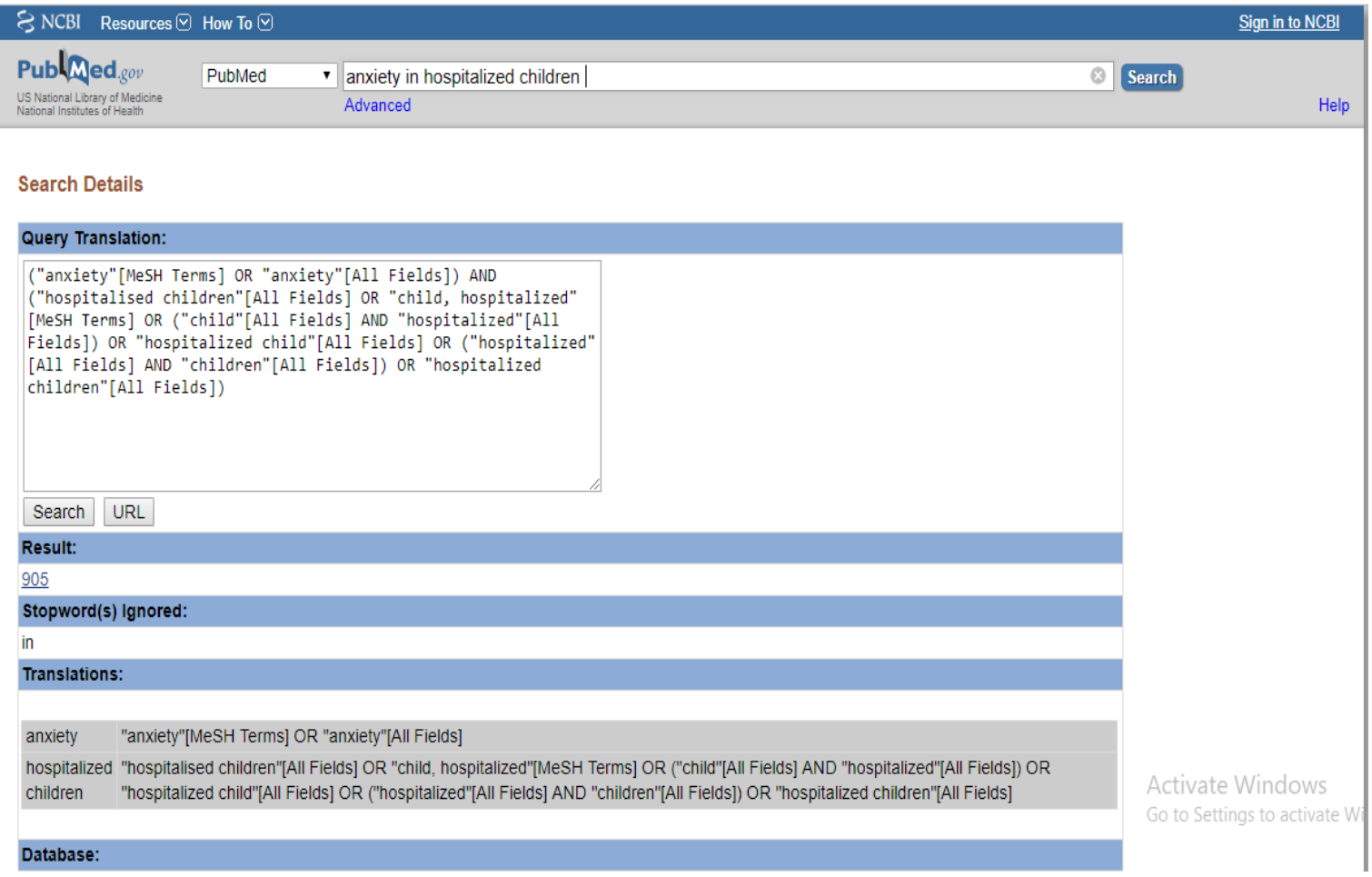




\begin{tabular}{|c|c|c|c|c|c|c|}
\hline $\begin{array}{l}\text { Ref. } \\
\text { no }\end{array}$ & Study title & Country & Sample & $\begin{array}{l}\text { Research } \\
\text { type }\end{array}$ & Methods & Findings \\
\hline 1. & $\begin{array}{l}\text { Effect of a Supportive } \\
\text { Training Program } \\
\text { on Anxiety in Children } \\
\text { with Chronic Kidney } \\
\text { Problems and their } \\
\text { Mothers' Caregiver } \\
\text { Burden }\end{array}$ & Iran & $\begin{array}{l}116 \text { children } \\
\text { with chronic } \\
\text { kidney } \\
\text { problems } \\
\text { who hospitaliz } \\
\text { ed }\end{array}$ & $\begin{array}{l}\text { randomized } \\
\text { controlled } \\
\text { clinical tria }\end{array}$ & $\begin{array}{l}\begin{array}{l}\text { Data was } \\
\text { through }\end{array} \text { collected } \\
\text { convenient } \\
\text { sampling technique } \\
\text { where Participants were } \\
\text { randomly assigned to } \\
\text { experimental }(\mathrm{n}=56) \\
\text { and control }(\mathrm{n}=56) \\
\text { groups by using } \\
\text { Face Anxiety Scale and } \\
\text { the Zarit Caregiver } \\
\text { Burden Scale. }\end{array}$ & $\begin{array}{l}\text { The results revealed } \\
\text { that the supportive } \\
\text { training program } \\
\text { reduce children's anxi } \\
\text { ety and caregiver } \\
\text { burden and also } \\
\text { effective to reduce the } \\
\text { negative effects of } \\
\text { hospitalisation. }\end{array}$ \\
\hline 2. & $\begin{array}{l}\text { Social Robots } \\
\text { for Hospitalized } \\
\text { Children }\end{array}$ & $\begin{array}{l}\text { Boston, } \\
\text { Massachuset } \\
\text { ts }\end{array}$ & $\begin{array}{l}\text { Fifty- } \\
\text { four children } \\
\text { with age group } \\
3 \text { to } 10 \text { years } \\
\text { were randomly } \\
\text { exposed }\end{array}$ & $\begin{array}{l}\text { Experimental } \\
\text { study }\end{array}$ & $\begin{array}{l}\text { Samples were randomly } \\
\text { exposed to } 1 \text { of } 3 \\
\text { interventions: } \\
\text { interactive SR teddy } \\
\text { bear; (2) tablet-based } \\
\text { avatar version of the } \\
\text { bear; or (3) plush teddy } \\
\text { bear with human } \\
\text { presence. We monitored } \\
\text { intervention enrollment } \\
\text { and completion patterns, } \\
\text { obtained qualitative } \\
\text { feedback, and } \\
\text { assessed children's } \\
\text { positive and negative } \\
\text { affect, anxiety, and pain } \\
\text { intensity pre- and } \\
\text { postintervention. }\end{array}$ & $\begin{array}{l}\text { The SR may provide } \\
\text { new ways to address } \\
\text { the emotional needs } \\
\text { of hospitalized } \\
\text { children, potentially } \\
\text { increasing access to } \\
\text { emotionally targeted } \\
\text { interventions. } \\
\text { Rigorous } \\
\text { development and } \\
\text { validation of SR } \\
\text { technology in } \\
\text { pediatrics les could } \\
\text { ultimately lead to } \\
\text { scalable and cost- } \\
\text { effective tools to } \\
\text { improve the patient } \\
\text { care experience. }\end{array}$ \\
\hline 3. & $\begin{array}{l}\text { Hospitalization anxiety } \\
\text { in children: conceptual } \\
\text { analysis }\end{array}$ & Brazil & $\begin{array}{l}\text { Available } \\
\text { literature } \\
\text { search }\end{array}$ & $\begin{array}{l}\text { methodologic } \\
\text { al study, with } \\
\text { a qualitative } \\
\text { approach }\end{array}$ & $\begin{array}{lr}\text { Searching for } & \text { possible } \\
\text { available } & \text { literature } \\
\text { (books, dictionaries, and } \\
\text { scientific } & \text { papers. } \\
\text { Keywords } & \text { anxiety } \\
\text {,hospitalization } & \text { and } \\
\text { children used } & \end{array}$ & $\begin{array}{l}\text { Facing } \\
\text { hospitalization, the } \\
\text { child may } \\
\text { demonstrate different } \\
\text { behaviors, among } \\
\text { them behaviors prior } \\
\text { to identification of } \\
\text { hospitalization } \\
\text { anxiety as a nursing } \\
\text { diagnosis and that } \\
\text { have not been } \\
\text { observed in the family } \\
\text { context before. }\end{array}$ \\
\hline 4. & $\begin{array}{l}\text { Effectiveness of origami } \\
\text { on hospitalized anxiety } \\
\text { among children }\end{array}$ & $\begin{array}{l}\text { India } \\
\text { tamilnadu }\end{array}$ & $\begin{array}{l}40 \text { children age } \\
6-12 \text { year }\end{array}$ & $\begin{array}{l}\text { Quantitative } \\
\text { research } \\
\text { approach. } \\
\text { two Group } \\
\text { Pre-test Post- } \\
\text { test Quasi- } \\
\text { experimental } \\
\text { research } \\
\text { design. }\end{array}$ & 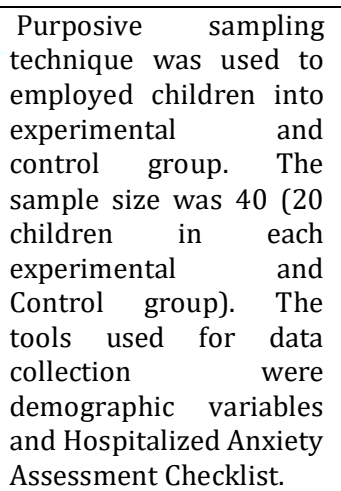 & $\begin{array}{lr}\text { Origami } & \text { helps } \\
\text { children to adapt } \\
\text { unpleasant situations } \\
\text { in better way, } \\
\text { especially during } \\
\text { hospitalization. This } \\
\text { healthy adaptation } \\
\text { promotes ruick } \\
\text { recovery from their } \\
\text { illness. }\end{array}$ \\
\hline 5. & $\begin{array}{l}\text { Assess the Effectiveness } \\
\text { of Art Therapy on Level } \\
\text { of Anxiety among } \\
\text { Hospitalized Children. }\end{array}$ & INDIA & $\begin{array}{l}60 \text { school age } \\
\text { children }\end{array}$ & $\begin{array}{l}\text { Quantitative } \\
\text { research } \\
\text { approach }\end{array}$ & \begin{tabular}{lrr} 
Non & probability \\
convenience & \multicolumn{2}{c}{ sampling } \\
technique & selected at \\
hospitals of & Wardha \\
District. Data & were \\
collected by & using \\
Modified & \multicolumn{2}{c}{ Spence } \\
children anxiety scale.
\end{tabular} & $\begin{array}{l}\text { The study findings } \\
\text { revels that } 17 \text { (56.66 } \\
\% \text { ) of the children } \\
\text { from experimental } \\
\text { group had severe } \\
\text { anxiety in pre-test } \\
\text { and none of child } \\
\text { from experimental } \\
\text { group had severe } \\
\text { anxiety in post test. }\end{array}$ \\
\hline 6. & $\begin{array}{l}\text { A New Mobile Application } \\
\text { to Reduce Anxiety in }\end{array}$ & Thailand & $\begin{array}{l}60 \text { patients age } \\
5 \text { to } 12 \text { years }\end{array}$ & $\begin{array}{l}\text { single- } \\
\text { blinded, }\end{array}$ & $\begin{array}{l}\text { Sixty participants were } \\
\text { randomly assigned to }\end{array}$ & $\begin{array}{l}\text { The child anxiety } \\
\text { visual analog scale }\end{array}$ \\
\hline
\end{tabular}




\begin{tabular}{|c|c|c|c|c|c|c|}
\hline & $\begin{array}{l}\text { Pediatric Patients Before } \\
\text { Bone Marrow Aspiration } \\
\text { Procedures }\end{array}$ & & $\begin{array}{l}\text { old who were } \\
\text { undergoing } \\
\text { bone marrow } \\
\text { aspiratio-n }\end{array}$ & $\begin{array}{l}\text { randomized } \\
\text { controlled } \\
\text { trial }\end{array}$ & $\begin{array}{l}\text { the intervention group } \\
\text { (mobile application } \\
\text { added to usual care) or } \\
\text { the control group (usual } \\
\text { carer only). } \\
\text { Preprocedural anxiety } \\
\text { levels were evaluated by } \\
\text { visual analog scales } \\
\text { (child anxiety visual } \\
\text { analog scale). }\end{array}$ & $\begin{array}{l}\text { score of patients in } \\
\text { the intervention } \\
\text { group decreased } \\
\text { significantly after } \\
\text { they used the mobile } \\
\text { application } \quad(\mathrm{P}< \\
\text {.0012). }\end{array}$ \\
\hline 7. & $\begin{array}{l}\text { Play interventions to } \\
\text { reduce anxiety and } \\
\text { negative emotions in } \\
\text { hospitalized children }\end{array}$ & $\begin{array}{l}304 \text { Chinese } \\
\text { children } \\
\text { (ages 3-12) }\end{array}$ & $\begin{array}{l}\text { Hong Kong } \\
\text { China }\end{array}$ & $\begin{array}{l}\text { Quasi } \\
\text { experimental } \\
\text { study with } \\
\text { non- } \\
\text { equivalent } \\
\text { control group } \\
\text { pre-test and } \\
\text { post-test, }\end{array}$ & $\begin{array}{l}\text { In the control group, } \\
\text { children received } \\
\text { standard medical and } \\
\text { nursing care, such as } \\
\text { vital signs observation, } \\
\text { pharmacological } \\
\text { treatment and wound } \\
\text { and pain management. } \\
\text { In the experimental } \\
\text { group, participants } \\
\text { received hospital play } \\
\text { interventions, conducted } \\
\text { by hospital play } \\
\text { specialists. }\end{array}$ & $\begin{array}{l}\text { Children who } \\
\text { received the hospital } \\
\text { play interventions } \\
\text { exhibited fewer } \\
\text { negative emotions } \\
\text { and experienced } \\
\text { lower levels of } \\
\text { anxiety than those } \\
\text { children who received } \\
\text { usual care. }\end{array}$ \\
\hline 8. & $\begin{array}{l}\text { The effect of } \\
\text { storytelling in a play } \\
\text { therapy on anxiety level } \\
\text { in pre-school children } \\
\text { during hospitalization } \\
\text { in the general hospital } \\
\text { of buton }\end{array}$ & Indonesia & $\begin{array}{l}30 \quad \text { pre } \\
\text { schooler } \\
\text { children }\end{array}$ & $\begin{array}{l}\text { quasi- } \\
\text { experimental } \\
\text { study with } \\
\text { pretest- } \\
\text { posttestcontr } \\
\text { ol group } \\
\text { design. }\end{array}$ & $\begin{array}{l}\text { Pre School - Spence } \\
\text { Children's Anxiety Scale } \\
\text { (SCAS) was used to } \\
\text { measure anxiety in } 30 \\
\text { pre-school children. }\end{array}$ & $\begin{array}{l}\text { There is a significant } \\
\text { influence of } \\
\text { storytelling in a play } \\
\text { therapy on anxiety } \\
\text { levels in preschool } \\
\text { children during } \\
\text { hospitalization. }\end{array}$ \\
\hline 9. & $\begin{array}{l}\text { Dental anxiety among } \\
\text { children of age between } \\
5 \text { to } 10 \text { years visiting a } \\
\text { teaching dental hospital } \\
\text { in islamabad, Pakistan }\end{array}$ & Pakistan & $\begin{array}{l}252 \text { children } \\
\text { aged between } \\
5-10 \text { years }\end{array}$ & $\begin{array}{l}\text { Cross } \\
\text { sectional } \\
\text { study }\end{array}$ & $\begin{array}{l}\text { Dental anxiety was } \\
\text { assessed by using the } \\
\text { Faces Version of the } \\
\text { Modified Child Dental } \\
\text { Anxiety Scale. }\end{array}$ & $\begin{array}{l}\text { This study has } \\
\text { highlighted dental } \\
\text { anxiety as a potential } \\
\text { public health concern } \\
\text { regarding children in } \\
\text { Pakistan. }\end{array}$ \\
\hline 10. & $\begin{array}{l}\text { Effectiveness } \\
\text { therapeutic play in } \\
\text { terms of anxiety and } \\
\text { behavioral response } \\
\text { among hospitalized } \\
\text { preschool children in } \\
\text { masonic hospital at } \\
\text { coimbatore }\end{array}$ & $\begin{array}{l}\text { Coimbatore, } \\
\text { india. }\end{array}$ & 60 samples & $\begin{array}{l}\text { one group } \\
\text { pre-test post- } \\
\text { test pre } \\
\text { experimental } \\
\text { design }\end{array}$ & $\begin{array}{l}\text { Purposive sampling } \\
\text { technique was used to } \\
\text { employ the sample. By } \\
\text { using anxiety rating } \\
\text { scale and behavioural } \\
\text { response rating scale to } \\
\text { assess the level of } \\
\text { anxiety and behavioural } \\
\text { response level. }\end{array}$ & $\begin{array}{l}\text { The result showed } \\
\text { that therapeutic play } \\
\text { to reduced anxiety } \\
\text { and improved } \\
\text { behavioural response } \\
\text { among hospitalized } \\
\text { preschool children }\end{array}$ \\
\hline 11. & $\begin{array}{l}\text { The Effects of } \\
\text { Preoperative } \\
\text { Recreational Activities } \\
\text { on Children's Anxiety } \\
\text { Level during the } \\
\text { Perioperative Period }\end{array}$ & Jordan & $\begin{array}{l}60 \text { sample of } 2- \\
7 \text { year age }\end{array}$ & $\begin{array}{l}\text { Quasi } \\
\text { experimental } \\
\text { design }\end{array}$ & $\begin{array}{l}60 \text { samples which was } \\
\text { employed by } \\
\text { convenience sampling } \\
\text { method are grouped into } \\
2 \text { part. modified Yale } \\
\text { Preoperative Anxiety } \\
\text { Scale (modified YPAS) } \\
\text { three times used for } \\
\text { measured anxiety level. }\end{array}$ & $\begin{array}{l}\text { Children in the } \\
\text { intervention group } \\
\text { exhibited lower level } \\
\text { of anxiety level than } \\
\text { control group. }\end{array}$ \\
\hline 12. & $\begin{array}{l}\text { Investigation of the } \\
\text { Fear of 7-18-Year-Old } \\
\text { Hospitalized Children } \\
\text { for Illness and Hospital. }\end{array}$ & Turkey & $\begin{array}{l}144 \text { children } \\
\text { who were } \\
\text { hospitalized }\end{array}$ & $\begin{array}{l}\text { Non } \\
\text { experimental } \\
\text { Descriptive } \\
\text { study }\end{array}$ & $\begin{array}{l}\text { Consent was taken. Data } \\
\text { were collected by face- } \\
\text { to-face interview } \\
\text { technique. Statistical } \\
\text { analyses were used to } \\
\text { assess data. }\end{array}$ & $\begin{array}{l}\text { It was observed that } \\
\text { children in the study } \\
\text { experienced fear for } \\
\text { illness and } \\
\text { hospitalization and } \\
\text { the percentage of } \\
\text { children with fears } \\
\text { was found to be high. }\end{array}$ \\
\hline 13. & $\begin{array}{l}\text { A study to assess the } \\
\text { effectiveness of play } \\
\text { activities in reducing } \\
\text { the level of anxiety } \\
\text { among hospitalized }\end{array}$ & $\begin{array}{l}\text { Banglore- } \\
\text { india }\end{array}$ & $\begin{array}{l}60 \text { children in } \\
\text { the } 2 \text { group }\end{array}$ & $\begin{array}{l}\text { A quasi- } \\
\text { experimental } \\
\text { study }\end{array}$ & $\begin{array}{l}\text { The convenient } \\
\text { sampling technique was } \\
\text { used to select } \\
\text { 60sample[experimental } \\
\text { group n=30, control }\end{array}$ & $\begin{array}{l}\text { The findings shows } \\
\text { that children were } \\
\text { seen anxious during } \\
\text { pre-test although and } \\
\text { during post-test }\end{array}$ \\
\hline
\end{tabular}




\begin{tabular}{|c|c|c|c|c|c|c|}
\hline & children. & & & & $\begin{array}{l}\text { group } n=30] \text { Data was } \\
\text { collected by using } \\
\text { hospital observed } \\
\text { behavior check list. }\end{array}$ & $\begin{array}{l}\text { children were not } \\
\text { anxious or decreased } \\
\text { anxiety so, it shows } \\
\text { that play activities } \\
\text { were effective method } \\
\text { for reduce the anxiety } \\
\text { level }\end{array}$ \\
\hline 14. & $\begin{array}{l}\text { The Effectiveness of } \\
\text { Storytelling on } \\
\text { Separation Anxiety in } \\
\text { Hospitalized Children } \\
\text { with Chronic Diseases }\end{array}$ & Iran & $\begin{array}{l}40 \text { samples } \\
\text { from } 4-7 \text { year } \\
\text { old age group }\end{array}$ & $\begin{array}{l}\text { quasi- } \\
\text { experimental } \\
\text { study with } \\
\text { pretest- } \\
\text { posttestcontr } \\
\text { ol group } \\
\text { design. }\end{array}$ & $\begin{array}{l}\text { Data were collected } \\
\text { from } 40 \text { hospitalized [ } 20 \\
\text { samples in each } \\
\text { group]children with } \\
\text { chronic diseases by } \\
\text { using random sampling } \\
\text { technique with use of } \\
\text { Spence's Preschool } \\
\text { Anxiety Scale tool. }\end{array}$ & $\begin{array}{l}\text { The results revealed a } \\
\text { storytelling reduced } \\
\text { significantly anxiety } \\
\text { in the children in the } \\
\text { interventional group } \\
\text { compared with } \\
\text { children who had not } \\
\text { received intervention. }\end{array}$ \\
\hline 15. & $\begin{array}{l}\text { The effectiveness of } \\
\text { therapeutic play, using } \\
\text { virtual reality computer } \\
\text { games, in promoting the } \\
\text { psychological well- } \\
\text { being of children } \\
\text { hospitalised with } \\
\text { cancer }\end{array}$ & Hong Kong & $\begin{array}{l}122 \text { children- } \\
70 \text { in control } \\
\text { group and } 52 \\
\text { in } \\
\text { experimental } \\
\text { group. }\end{array}$ & $\begin{array}{l}\text { non- } \\
\text { equivalent } \\
\text { One group } \\
\text { pre-test post } \\
\text { test }\end{array}$ & $\begin{array}{l}\text { A planned intervention } \\
\text { of computer based game } \\
\text { introduced among } \\
\text { intervention group. }\end{array}$ & $\begin{array}{l}\text { The Investigator } \\
\text { concluded that study } \\
\text { provides evidence to } \\
\text { support the effective } \\
\text { use of virtual } \\
\text { computer game as a } \\
\text { therapeutic play can } \\
\text { minimize the anxiety } \\
\text { and depressive } \\
\text { symptoms among } \\
\text { hospitalized children } \\
\text { with cancer. }\end{array}$ \\
\hline 16. & $\begin{array}{l}\text { Effect of Toys and } \\
\text { Preoperative Visit on } \\
\text { Reducing Children's } \\
\text { Anxiety and their } \\
\text { Parents before Surgery } \\
\text { and Satisfaction with } \\
\text { the Treatment Process }\end{array}$ & Iran & $\begin{array}{l}60 \quad \text { children } \\
\text { with } 3-8 \text { year } \\
\text { old children }\end{array}$ & $\begin{array}{l}\text { quasi- } \\
\text { experimental } \\
\text { study in } \\
\text { posttest } \\
\text { design }\end{array}$ & $\begin{array}{l}\text { The level of anxiety in } \\
\text { children and parents } \\
\text { was evaluated by } \\
\text { Observation Scale of } \\
\text { Behavioral Distress } \\
\text { (OSBD-R) and } \\
\text { Spielberger } \\
\text { Anxiety State } \\
\text { (STAI). The level of } \\
\text { parental satisfaction } \\
\text { with the treatment } \\
\text { process was evaluated } \\
\text { by the process of } \\
\text { treatment satisfaction } \\
\text { questionnaire (PSQ-18). }\end{array}$ & $\begin{array}{l}\text { Based on the findings, } \\
\text { providing toys for } \\
\text { children and } \\
\text { informing the parents } \\
\text { about medical } \\
\text { information has a } \\
\text { major effect in } \\
\text { reducing children's } \\
\text { and other's anxiety } \\
\text { and increasing } \\
\text { maternal satisfaction } \\
\text { with the treatment } \\
\text { process. }\end{array}$ \\
\hline
\end{tabular}

\section{Inclusion and exclusion criteria for article} selection

\section{Inclusion criteria}

1. The research paper only which directly belongs to hospitalized anxiety among children due to any cause.

2. The paper which is easily accessible online and full text available.

3. The studies which are carried out in English language.

4. Articles which having minimum 60 samples in study.

5. Research conducted between 2010 to 2019 are included.

\section{Exclusion criteria}

1. The study concern to adult.

2. The studies which are duplicate and result are ambiguous.

3. The research study which is published in without ISSN No journals.

4. The research studies which are not available on journal database.

5. The research studies in which only abstract is available.
6. Research carried out before 2010.

\section{RESULT}

Researcher found 905 research paper from electronic data base. Out of 905, 1012 from PubMed, 212 from ERIC, 24 from PsycINFO, 180 from ProQuest database. 134 articles are excluded as they were duplicates in the databases. 184 articles are excluded as they are not available in full text.

\section{Search strategy in PubMed}

MeSH terminology used for PubMed and ERIC ("Anxiety among hospitalized children"[MeSH Terms] OR

("Anxiety"[All Fields]AND "Children"[All Fields]) OR "During hospitalization".

\section{Image}

The overall findings of study shown that QOL affected by age, seizure frequency, parent's education, socialstigma, cultural practices, type of epilepsy, and type of anti-epileptic in children with epilepsy. Cognition, energy levels and concentration are most commonly affected due toepilepsy. QOL can be assessed by generic or disease specific measures. Generic measures of QOL assess function, disability and distress resulting from general ill health and have the 
advantages of allowing comparisons with healthy population. Quality of life ( $(\mathrm{QOL})$ is concerned with "the degree to which a person enjoys the important possibilities of life. Health-related quality of life (HRQOL $)$ characterizes a person's perception of how health influences an individual's life quality and overall well-being. Quality of life is an important measurable outcome of care for conditions that do not threaten life.

\section{DISCUSSION}

The objective of this paper is to provide an insight amonghealth care workers regarding how to reduce the level of anxiety among hospitalized children. Various types of methods had been used by researcher to reduce the anxiety level among children such as play therapy, diversion therapy, storytelling, music therapy, origami technique, guided imaginary, drawing and color, apply quiz etc. A common intervention can be planned to reduce the anxiety among children and their parents too. A common planned intervention will be helpful to reduce anxiety.

\section{CONCLUSION}

This review paper is concluded that there are various causes of child anxiety in hospital. A proper strategy can be planned to reduce anxiety. It is expected that this study will play a role in clarifying of the concept of anxiety in hospitalized children in such a way that a planned intervention (Play activity + Story telling + Puzzle+ thinking Process) can be easily identified in child health care in hospital. This paper helps to promote quality in the process of developing paediatric care.

\section{ACKNOWLEDGEMENT}

\section{REFERENCES-}

1. Bahrami N, Pahlavanzadeh S, Marofi M. Effect of a Supportive Training Program on Anxiety in Children with Chronic Kidney Problems and their Mothers' Caregiver Burden. Iran J Nurs Midwifery Res. 2019 May-Jun;24(3):193-199. doi:

10.4103/ijnmr.IJNMR_88_18. PubMed PMID: 31057635; PubMed Central PMCID: PMC6485030.

2. Logan DE, Breazeal C, Goodwin MS, Jeong S, O'Connell B, Smith-Freedman D, Heathers J, Weinstock P. Social Robots for Hospitalized Children. Pediatrics. 2019 Jul;144(1). pii: e20181511. doi: 10.1542/peds.2018-1511. PubMed PMID: 31243158.

3. Gomes GLL, Fernandes MGM, Nóbrega MML. Hospitalization anxiety in children: conceptual analysis. Rev Bras Enferm [Internet]. 2016;69(5):884-9. DOI: http://dx.doi.org/10.1590/0034-7167-2015-0116

4. Mathew Christy Susan, evaluate the effectiveness of origami on level of anxiety among hospitalized children ,International Journal of Advance Research and Development 2018, Volume3( Issue 8) Available online at: www.ijarnd.com

5. Kamini P. Sao, ArchanaMaurya, Assess the Effectiveness of Art Therapy on Level of Anxiety among Hospitalized Children. International Journal of Science and Research (IJSR) ISSN (Online): 2319-7064

6. PornchanokWantanakorn et all "A New Mobile Application to Reduce Anxiety in Pediatric Patients Before Bone Marrow Aspiration
Procedures" HOSPITAL PEDIATRICS Volume 8, Issue 10, October 2018

7. William H. C. Li, Joyce Oi Kwan Chung, Ka Yan Ho, Blondi Ming Chau Kwok Play interventions to reduce anxiety and negative emotions in hospitalized children BMC Pediatrics, 2016, Volume 16, Number 1, Page

1https://bmcpediatr.biomedcentral.com/articles/10.1186/s1 2887-016-0570-5

8. Yati M, Wahyuni S, Pratiwi DS, Islaeli. The Effect of Storytelling in a Play Therapy on Anxiety Level In Pre-School Children during Hospitalization in the General Hospital of Buton. Public Health of Indonesia 2017;3(3):96-101Link https://pdfs.semanticscholar.org/3adf/c002f89446ef9f1994 1e43ddd6766f9a9a86.pdf

9. J Ayub Med Coll Abbottabad 2015;27(3):587-90 Address for Correspondence: Dr.GulrezHanif Raja, C/O. Col. Muhammad Hanif (R), H. No.10, Street-15, Sector-D, DHA-2, IslamabadPakistan Cell: +92 300410 6977/ +92 3454053438 Email: dr.gulrez@live.com

10. Miss.G.Ruby, Effectiveness Of Therapeutic Play In Terms of Anxiety And Behavioural Response Among Hospitalized Preschool Children In Masonic Hospital At Coimbatore,20092011[Cited On 11th May,2018] Available Form : https://repository-tnmgrmu.ac.in/5678/1/3002065rubyg

11. HalaObeidat, The Effects of Preoperative Recreational Activities on Children's Anxiety Level during the Perioperative Period International journal of Rural Development, Environment and Health Research(IJR EH) Sep-Oct, 2017,Volume-1, (Issue-3) PP- 2456-8678 Available form

https://www.academia.edu/34951490/The_Effects_of_Preop erative_Recreational_Activities_on_Childrens_Anxiety_Level_d uring_the_Perioperative_Period

12. ÖztürkŞahin Ö, Topan A. Investigation of the Fear of 7-18Year-Old"Hospitalized Children for Illness and Hospital. J Relig Health. 2019 Jun;58(3):1011-1023. doi: 10.1007/s10943-018-0688-x. PubMed PMID: 30136136

13. Titi Xavier, Sagayamary" A study to assess the effectiveness of play activities in reducing the level of anxiety among hospitalized children" IOSR Journal of Nursing and Health Science (IOSR-JNHS) Volume 3, Issue 2 Ver. IV (Mar-Apr. 2014), PP 59-62 http://www.iosrjournals.org/iosrjnhs/papers/vol3-issue2/Version-4/L03245962.pdf

14. Seyedeh Mina Shafiee, The Effectiveness of Storytelling on Separation Anxiety in Hospitalized Children with Chronic Diseases, Journal of Research in Medical and Dental Science 2018, Volume 6( Issue 5) Page No: 284-290 Available Online at: www.jrmds.in

15. William HC Li, Eva KY Ho The effectiveness of therapeutic play, using virtual reality computer games, in promoting the psychological well-being of children hospitalised with cancer, , Journal of Clinical Nursing 2011 PP 2135-2143 Available form:

https://www.academia.edu/11211003/The_effectiveness_of_ therapeutic_play_using_virtual_reality_computer_games_in_pr omoting_the_psychological_wellbeing_of_children_hospitalised_with_cancer

16. Ghabeli, F., Moheb, N., \&HosseiniNasab, S. D. (2014). Effect of Toys and Preoperative Visit on Reducing Children's Anxiety and their Parents before Surgery and Satisfaction with the Treatment Process. Journal of caring sciences, 3(1), 21-28. doi:10.5681/jcs.2014.003https://www.ncbi.nlm.nih.gov/pmc /articles/PMC4134164/ 